\author{
Lukáš BEBR ${ }^{1}$ \\ Kateřina BÍCOVÁ
}

\title{
FMEA AND ITS APPLICATION IN THE SPC
}

\begin{abstract}
In today's industry, particularly in the automotive industry, the Failure Mode and Effects Analysis (FMEA) method is a frequently used tool. FMEA is one of the tools which help to identify the causes of process variability and thereby the possibilities of defect occurrence in the evaluated design including the evaluation of their relevant risks. This paper describes the application of the FMEA method to the manufacturing process, with the aim to identify the main causes of process variability, which can affect the resulting product. Further the article introduces other types of FMEA methods based on the basic model, however tailored for specific use in various areas. Finally, the measures, actions and recommendations for correct implementation of the FMEA process are mentioned.
\end{abstract}

Keywords: FMEA, SPC, quality, diagram, variability, process

\section{Introduction}

In today's industry, particularly in the automotive industry, the Failure Mode and Effects Analysis (FMEA) method is a frequently used tool and is based on a deterministic method of analysis. It was developed in the 1960's in the US during NASA's APOLLO space program as a tool for finding serious risks. The first civilian use of this method was by Ford about 10 years later due to the poor quality of the Ford Pinto project on which this method was firstly used. In the early 1980 's, the FMEA method was made into an integral manual and was included in the QS 9000 standard [1]. FMEA is one of the tools which help to identify the most critical and most likely errors in a product or process. They provide for the prevention of various causes of process variability, and hence possible defects in the design, including the assessment of their risks. At the beginning of using FMEA, we should address the questions shown in Figure 1.

\footnotetext{
${ }^{1}$ Autor do korespondencji/corresponding author: Lukáš Bebr, University of West Bohemia in Pilsen, Univerzitní 22, Pilsen 301 00, Czech Republic, tel.: +420377638529, e-mail: bebrl@kto.zcu.cz

${ }^{2}$ Kateřina Bícová, University of West Bohemia in Pilsen, e-mail: kbicova@kto.zcu.cz
} 


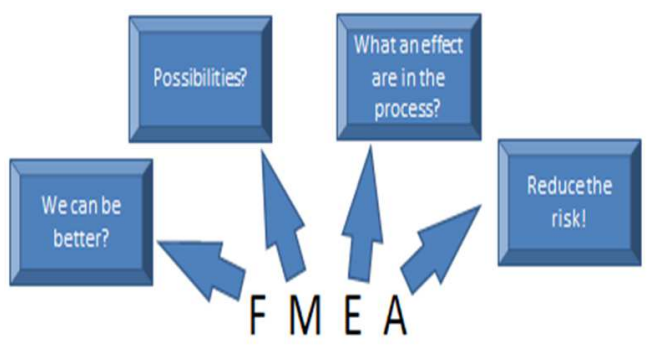

Fig. 1. What with FMEA?

\section{SPC and variability}

To observe the behaviour of processes, the SPC method is probably the most often used statistical method in manufacturing organizations. The basic aim of the regulation is improving quality and bringing the process to a stable state and to maintain it.

Resolution and identification of the causes of variability (random or definable), which affect the process, are performed by use of control charts [2]. These diagrams are in fact graphic representations of the process variability in time with upper and lower control limits and enable:

- it is a tool for process control - the regulation contains measures to be taken if the results are nonconforming (Fig. 2),

- detection and monitoring of the process (Fig. 3),

- distinction of special causes of variation from random.

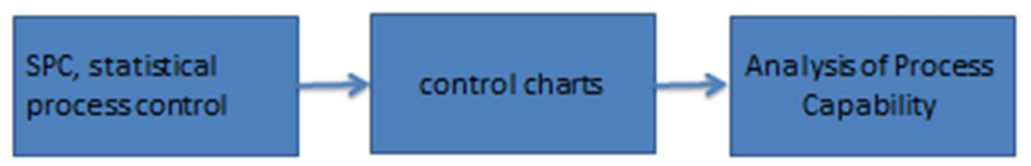

Fig. 2. SPC

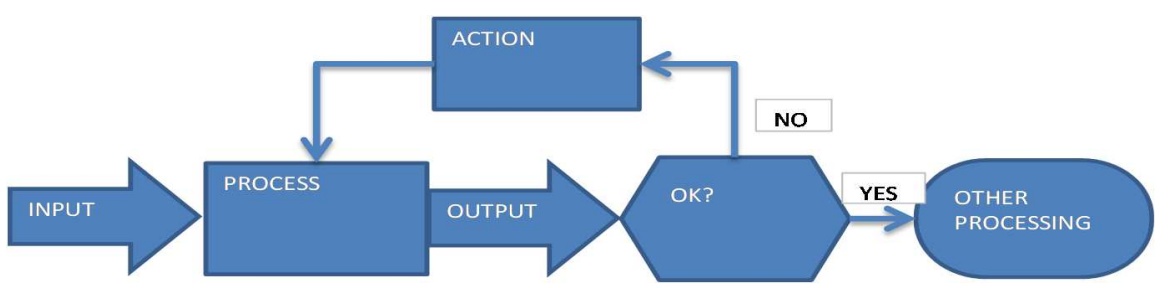

Fig. 3. Process control

If we try to improve the manufacturing process, then we should primarily define and uncover the causes that are a source of substantial and undesirable changes in the monitored process and thus affect the quality characteristics, which 
we observe. The causes may happen by chance or they are assignable. Random effects - chance causes [3]:

- according to the CSN 010265 standard, the random fluctuations of the manufacturing process attributes the effect of random impacts,

- according to in the CSN IS 8258 standard random fluctuations in the production process is understood as a consequence of global action of accidental causes that are inherent component of the manufacturing process.

Systematic effects - assignable causes [3]:

- definable causes refer to an identifiable cause, producing a real change in the manufacturing process; while the ISO 8258 standard requires these types of causes to be identified to prevent their recurrence,

- CSN 010265 standard merely states that the systematic influences can run concurrently with some random influences and act upon the values regulated quality indicator. Thus the concept of the ISO 8558 standard more comprehensive, and further new term "identifiable cause" shall characterize above formulated requirements: identification-> correction-> Prevention.

Through detection and reduction of such identifiable causes we therefore strive to eliminate systemic non-random variability (i.e., variability). These nonrandom causes are caused by different factors, which vary according to the nature of the production process, for example:

- influence of environment (humidity, temperature),

- influence of the measuring device (wrong calibration, damage),

- influence of machines (poor alignment, adjustment, maintenance),

- influence of material (defects, poor delivery),

- influence of employee (shift influence on the measurements, the new operator), etc...

There are many factors that can influence and distort the results. Some changes are coming gradually, and therefore they are even more difficult to detect (gradual wear and tear of machine or tools ...). Among the methods for revealing fragility/process variability and helping to find causes belongs e.g.:

- analysis of repeatability and reproducibility,

- FMEA,

- FTA,

- diagram of causes and effects, i.e., Ishikawa diagram,

- Pareto analysis,

- 8D-Report, etc ...

During the last 20 years, the FMEA has gradually developed and expanded, for example, the VDA, DRBFM, FMECA, etc., have been developed or are based on this method [1]. In some analyzes, using a scale 1 to 4 or 5, in some, such as FMECA widely used in the automotive industry to analyze the proposal known as DFMEA (Design FMEA) and analysis of the production process known as PFMEA (Process FMEA) the same scale for all three attributes 1 to 10 is used. 
Or it is used too in SFMEA (System Failure Mode and Effect Analysis) [4]. Besides, to all processes the basic methodology known as PDCA (deming cycle) can be applied: "Plan-Do-Check-Act". PDCA can be briefly described as follows:

- plan: establish the objectives and processes necessary to deliver results in accordance with customer requirements and the organization's policies,

- do: apply processes,

- check: monitor and measure processes and product against policies, objectives and requirements for the product and report the results,

- act: take actions to continually improve process performance.

Revealing of identifiable causes is always followed by measures such as:

- employee training,

- sorting of materials,

- new machine,

- machine adjustment or maintenance, etc ...

The disadvantage of this method is that it does not affect the results of the operation or equipment failure caused by software errors. The impact of these phenomena can be observed by other methods, such as an analysis of the causes and consequences (Cause-Consequence Analysis CCA).

\section{Methodology of FMEA}

The application of the FMEA method to the process is usually done when designing a process for the production of new or upgraded products, or when changing the process [5-10]. The FMEA process is also a very valuable method of improving the processes already in use and can be applied to non-production processes. When applying the FMEA method to a process, the individual processes are first identified and the entire process is displayed using the flowchart. Then, it gradually analyzes all possible defects that can occur on the processed product during the individual processes. For each possible fault, all possible consequences of the defect are analyzed. These consequences are the possible impacts of the defect on an external customer, internal customers (concur processes), or process handlers. Possible causes described in the text above are analyzed for each possible defect. There are possible shortcomings of the proposed process (e.g. inappropriate process parameters) that could lead to the occurrence of the defect. Preventive measures are also identified to reduce the likelihood of possible defects and the control procedures used to detect or detect a defect. Analysis FMEA process is simplified in the following stages:

a) analysis and assessment of the current situation,

b) draft measures,

c) an assessment of the situation after the implementation of the measures,

d) the FMEA analysis results are continuously recorded in a standardized form, see the example in Figure 4. 


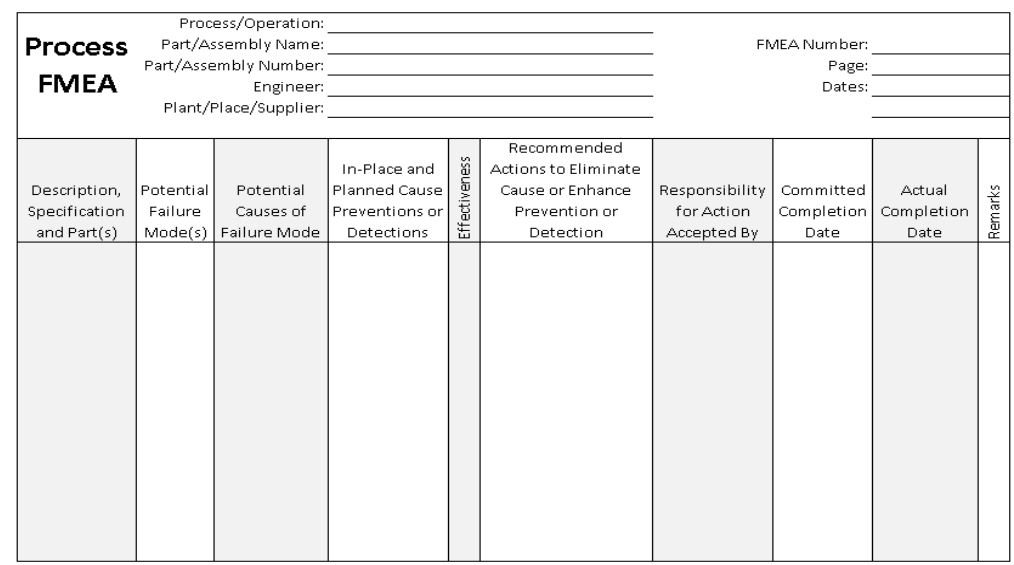

Fig. 4. Process FMEA

\section{Step-by-step steps:}

1. Definition:

a) examination of FMEA validity,

b) Clear Production Concept,

c) build an implementation team - preferably from a diverse range of experienced professionals (designers, developers, technicians, sales-men, etc.),

d) decomposition of the Process into Individual Processes.

2. Structural analysis:

a) the product is at the highest level, then we will look at the Process monitoring (Design FMEA),

b) we then best follow the assembly and process steps.

3. Performance and performance analysis:

a) description of the primary functions of valuable process steps,

b) ensuring that the required properties are created,

c) again the below noted topics can be used, e.g. what do workers or machines do to ensure the required properties in production?

4. Error analysis:

a) analysis of possible defects (possible defects that may occur on the processed product during the implementation of the partial activities of the proposed process),

b) analysis of possible consequences of defects (assessing their impact on external customers, subsequent processes, or machine operation),

c) analysis of possible causes of defects. (the deficiencies of the proposed process are assessed) The topics described below are used at this level.

5. Definition of the measure: analysis of existing preventive measures (analysis of the measures used to reduce the likelihood of a defect). 
6. Preparation and presentation:

a) analysis of existing control methods (analysis of control procedures to detect defects or their causes),

b) assessment of significance, expected occurrence and detectability of possible defects (Rating according to tables on a scale of 1 to 10 points, significance is evaluated according to the most serious consequence, the occurrence evaluates the likelihood of a defect caused by a particular cause, and the detectability is the ability to detect the defect or its cause by means of the existing control methods),

c) calculation of the risk numbers and their comparison with the critical value (the risk number (RPN) is value, significance, and detectability and is compared to the critical value typically determined by the customer (e.g. RPNcrit $=125)$ ),

d) proposal and implementation of risk mitigation measures (for all possible defects whose the risk number exceeds the critical value, it provides for measures that could reduce the risk of possible defects).

7. Rating: isk assessment after the implementation of the measures (once the measures have been re-evaluated, the significance, incidence and detectability are re-evaluated and the risk number is compared with the critical value) - i.e., repeating the whole process again.

Process FMEA is generally precisely set up by standards. In rare cases an open discussion is allowed about the process and afterwards specific questions are being asked. The following topics should always be discussed by the FMEA Process Moderator:

- Man - What is expected of a man in production? (manual work...).

- Machine - Do not confuse with machine FMEA; Toolings shall support the workers in their activities.

- Material - Material properties.

- Method - What is theoretically possible is possible in practice?

- Methods - Sequencing - Is the time sequence of work steps correct?

- Measurement - Process measurement could be too demanding.

- Current working conditions - Job requirements.

- Management - Team building, ...

\section{Conclusions}

Considering increasing customer demands regarding quality and reliability, the number and complexity of manufactured products are ever increasing. This also generates needs and higher requirements on development and production. Unfortunately, at the same time shorter development and testing times are increasingly required and parallel there is a strong pressure on cost reduction and rationalization. 
Process FMEA properly implemented, is a systematic approach to prevent non quality and reduce losses due to low system quality. It will also provide us the basic groundwork for improving and better processing of quality plans. FMEA optimizes design and reduces the amount of changes needed in the implementation phase, allowing us to do the right thing right the first time. We create herewith also a very valuable information system database, usable for other similar systems (e.g. production engineering, design).

Process FMEA requires a great deal of experience with the analyzed system needed for the correct identification of possible defects and their consequences. The FMEA is largely based on professional experience and, moreover, it is highly recommended to have multi-qualified teams, with multiple members whose knowledge and experience are mutually exclusive.

Finally, it should be noted that by using this tool we improve our brand/trade name and competitiveness of the organization, while helping to increase customer satisfaction. Costs incurred by implementing FMEA are only a fraction of the costs and damages which would arise in the event of non-compliance.

\section{Acknowledgment}

This article was created under the project SGS-2016-005: Research and development for innovations in the field of mechanical engineering technology machining technology.

\section{References}

[1] FMEA (Failure Mode and Effect Analysis). [In:] ManagementMania.com [online]. Wilmington (DE) 2011-2017, 20.04.2016 [cit. 16.06.2017]. Dostupné z: https://managementmania.com/cs/failure-mode-and-effect-analysis.

[2] http://www.chaloupka-kvalita.cz/spc-merenim (last access: January 2017).

[3] ČSN EN 60812, Analysis techniques for system reliability - Procedure for failure mode and effects analysis (FMEA), January 2007.

[4] Skopal J.: Uplatnění technických norem $\mathrm{v}$ malých a středních strojírenských firmách, Příručka č. 4.

[5] http://www.engineeringarchives.com/ref_processimprovement_processfmeaform. html (last access: 22.05.2017).

[6] http://isgwww.cs.uni-magdeburg.de/sim/vilab/2003/presentations/.

[7] FMEA KONKRET, Magazin, ISSN 2198-6851.

[8] Nenadál J. a kol.: Moderní management jakosti, Management press, Praha 2011, ISBN: 978-80-7261-186-7.

[9] Analýza možných způsobů a důsledků poruch (FMEA), 4.vydání, Česká společnost pro jakost, Praha 2008, ISBN: 978-1-60534-136-1.

[10] http://www.svetproduktivity.cz/slovnik/FMEA-Analyza-pricin-a-dusledku.htm. 


\section{ZASTOSOWANIE FMEA W SPC}

\section{Streszczenie}

Obecnie w branży przemysłowej, szczególnie w przemyśle motoryzacyjnym, często stosuje się analizę rodzajów błędów oraz ich skutków (FMEA). FMEA jest jednym z narzędzi, które pomagają w identyfikacji przyczyn zmienności procesu, a tym samym możliwości wystąpienia usterki w ocenianym projekcie i ocenie jej istotnych zagrożeń. Niniejszy artykuł opisuje zastosowanie metody FMEA do analizy procesu produkcyjnego w celu zidentyfikowania głównych przyczyn zmienności tego procesu, które mogą wpływać na otrzymany wyrób. Jej celem jest określenie najlepszego podejścia, pozwalającego na osiągnięcie najbardziej pożądanych wyników. Ponadto w artykule przedstawiono inne typy metody FMEA, oparte na modelu podstawowym, które są dostosowane do konkretnego zastosowania w różnych dziedzinach. Omówiono środki, działania i zalecenia dotyczące prawidłowego wdrożenia procesu FMEA.

Słowa kluczowe: FMEA, SPC, jakość, diagram, zmienność, proces

DOI: $10.7862 / \mathrm{rm} .2017 .23$

Otrzymano/received:12.06.2017

Zaakceptowano/accepted: 23.09.2017 